
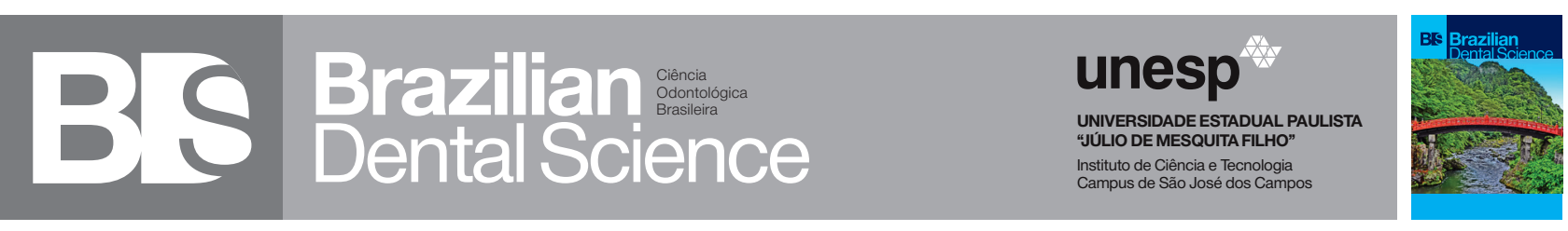

\title{
Digital marketing in dentistry and ethical implications
}

\author{
Marketing digital em odontologia e implicações éticas
}

Ana de Lourdes Sá de LIRA ${ }^{1}$, Bruna Mouzinho MAGALHÃES ${ }^{1}$

1 - Department of Clinical Dentistry - School of Dentistry of State University of Piauí - Parnaíba - PI - Brazil.

\begin{abstract}
With the increase of competition in the market of dental services, it is necessary to use marketing tools that emphasize the dental surgeon and dental clinics. Digital marketing is one of the fastest growing available resources among health professionals, who use websites and social networks as a means of communication, advertisement and publicity. The objective of this literature review was to compare the digital marketing with other marketing strategies in dentistry based on the code of ethics, in order to increase productivity, capture new patients and loyalty of those in treatment. Indexed searches were carried out in the databases LILACS, MEDLINE, SCIELO, BIREME, PORTAL CAPES and included 27 articles, published between 1998 and 2017. It was concluded that digital marketing has shown to be of great importance in the dental services market, if in conjunction with the other types of external and internal marketing, as long as it obeys the ethical precepts of the Dental Ethics Board.
\end{abstract}

\section{KEYWORDS}

Dental ethics; Marketing; Marketing of health services; Social media.

\section{RESUMO}

Com o aumento da concorrência no mercado de serviços odontológicos, se faz necessário utilizar ferramentas de marketing que destaquem o cirurgião-dentista e as clínicas odontológicas. O marketing digital é um dos recursos disponíveis que mais vem crescendo entre os profissionais da saúde, que utilizam de websites e redes sociais como meio de comunicação, de propaganda e publicidade. O objetivo desta revisão de literatura foi comparar o marketing digital com as demais estratégias de marketing na odontologia baseados no código de ética, a fim de aumentar a produtividade, captação de novos pacientes e fidelização daqueles em tratamento. Foram feitas pesquisas indexadas nas bases de dados LILACS, MEDLINE, SCIELO, BIREME, PORTAL CAPES e incluídos 27 artigos, publicados entre 1998 e 2017. Conclui-se que o marketing digital tem mostrado ser de grande importância no mercado de serviços odontológicos, se em conjunto com os demais tipos de marketing externo e interno, desde que obedeça aos preceitos éticos do Conselho de Ética Odontológico.

\section{PALAVRAS-CHAVE}

Ética odontológica; Marketing; Marketing de serviços de saúde; Mídias sociais.

\section{INTRODUCTION}

$\Gamma$ he dental office should be seen as a company, 1 and as such, should have in its planning part of the budget aimed at attracting and retaining customers. Capture today must occur in an efficient way so that the prospective client sees the professional as someone who is competent, competent and who passes security [1].
According to Miranda et al. [2] Marketing can be divided into internal and external. The intern includes the relationship with the patient, the resources available in the business, use of modern equipment, logo display in the workplace, as well as the quality of services. The external goes beyond the work environment, aimed at capturing patients, advertising and advertising the brand, promoting services 
and inducing the purchase, including digital marketing. It is possible to use digital media in both customer acquisition and customer loyalty, using Internet resources to disseminate dental knowledge, clinic and services, as well as encouraging communication between potential clients and the surgeon dentist (SD) [3].

It is also extremely important that the SD is aware of the ethical precepts, in force in the Code of Ethics, when using the advertising and marketing tools. The Code of Ethical Dentistry (CED) is easily found, however, several surveys expose ethical violations in their marketing tools [4-7].

There is a need for education and awareness of the professionals, as well as greater performance of the agencies responsible for the supervision of dental marketing, pointing out, warning and penalizing the violations found [5].

It was decided to do this work, because it is supposed to be necessary for the SD to become familiar with digital marketing, which is a far-reaching and easy-to-execute tool that involves digital assets such as blogs, social networks, websites, after the market research on public yearnings, professional-patient relationship, professional productivity and methods of patient loyalty. It is also essential to discuss their relationship with other marketing strategies and with the CED.

The objective of this literature review was to compare digital marketing with other marketing strategies in dentistry based on the code of ethics, in order to increase productivity, capture new patients and loyalty of those under treatment.

\section{METHOD}

The research was carried out in the databases LILACS, MEDLINE, SCIELO, BIREME, PORTAL CAPES. The descriptors used were: digital marketing (web marketing), digital marketing in dentistry, marketing in dental, dental ethics. Articles published between 1998 and 2017 were included, totaling 27 studies.

\section{Internal marketing/ Outbound marketing}

In order for the patient to feel confident about the proposed treatment, it is necessary to develop marketing strategies from the moment of their market research, to their experience and comfort in the clinical environment [8].

According to Paranhos et al. [9] marketing is a set of studies, strategies and practices that launch a product or service to the public, according to the analysis of their needs, and seeks to maintain its success in the market, thus constituting the success of the company.

Although targeted for teaching purposes, the types of marketing and the strategies created must be interlinked and equivalent in their functions so that there is success and positive differentiation in the face of market competition. With this, the structure and modernization of the clinic, the identification of the internal needs and their due investments, the qualification of the team, the creation of the brand and of communication channels in the digital media for the strengthening of the team-client relationship, must be a set active of artifice [3].

According to Vasudevan [10] the purchase decision is linked to the needs of the consumer and the marketing must be in accordance with their desires. It should not be limited to advertising and sales, but it must be a set of processes of creation, communication and supply of values for the customer, meeting the consumer's wishes [3].

Based on this Esperidião and Trad [11] affirmed that customer opinion and customer satisfaction are of great value in the design of goals and in the way in which each marketing segment inside and outside the company will be initially directed. Based on this principle satisfied client tends to adhere to the treatment and use the services of the clinic more frequently and safely.

\section{Internal marketing}

According to Garbin et al. [12] there 
are factors related to SD, other professionals and the dental office, which clients consider indispensable for their satisfaction in health services. For more than $50 \%$ of the interviewees, the use of PPE (gloves, cap, mask, white clothing and lab coat) shows to be important or very important by the dental team, especially the dental surgeon. As well as the humanization in the exercise of the profession, the fulfillment of the schedules, the efficient scheduling and the conduct of the assistants and receptionists.

Arcier et al. [13] also emphasized that an organized patient return system, whether by telephone contact, direct mail or e-mail, is an important marketing tool for customer loyalty. They observed, therefore, that the good service receives more attention even before the professional's titration or the determined prices.

It has been recommended the use of modern and technological equipment in clinical procedures and diagnosis as an internal marketing tool, as well as the use of audiovisual multimedia resources to explain treatment options and preventive measures to the patient. For the same purpose, the provision of printed matter, such as leaflets and enlightening folders, within reach of the clients in the offices and reception is convenient, always having the logo of the clinic with ample visualization in these materials [14].

Paranhos et al. [9] suggested as an efficient and inexpensive means of conquering new patients and retaining those who are being treated in the clinic, occupying the patient's time in the dental office during their treatments, using resources such as music, video clips and movies as a form of auditory stimulus. This to meet the unfeasible need that the client has to speak during the procedures.

In the practice of dental service marketing, this set of tools used in daily clinical and administrative, is called "marketing mix", which emphasizes the product (the service, its quality and everything that will satisfy the (customer perceived value), place (place where the service will be provided) and promotion (communication, personal marketing, advertising and advertising, relationship marketing and digital) [15].

In the 1950s, it was believed that marketing should be based on customer needs (relationshipmarketing), ata timewhenbusiness relationships were restricted and consequently intimate, with mutual trust between consumer and merchant / service provider, humanization in communication, customer satisfaction and loyalty [16]. However, the previously existing ties of communication and relationships in commerce were broken as a result of increasing mass production and marketing, where there would be no time or space for intimacy in the commercial environment, giving rise to the media as a new means of communication with the consumer. Currently, the quest to revitalize humanization and reliability relationships have been extolled, but strategically, maintaining the broad scope of the service, that is, ensuring large-scale visualization and production [1719].

The SD should not only concern itself with advanced technical resources, professional training and an elegant work environment, but must add to these factors the presence of strong team-client interaction, with an emphasis on attention, respect and commitment [14]. Relationships are not only through personal contact in the clinical environment, but there is also an intense and daily virtual interactivity network that must be taken into account when talking about relationship marketing today. In digital platforms, the SD is able to relate to thousands of people, creating good content of value and maintaining the wide range of reach that the competitive market requires [20,21].

\section{Outbond marketing}

According to Miranda et al. [2] outbound marketing and its media (such as magazines, 
radio, television and the internet) is the most commonly used CD. This is done beyond the work environment, with the purpose of making the enterprise known and emitting reliability, covering advertising and advertising [14]. Guimarães Júnior et al. [16] affirmed that the most used promotion strategy is still the advertisement of printed newspaper, followed by pamphleteering, billboards, gifts and telephone catalogs, sound cars, TV and radio employees. Standardized uniforms, as well as custom printed business cards and business cards, should also be used as a means of visualizing the brand.

Another effective but little applied communication tool is direct mail, if written in an explanatory, intelligent and creative way, and it is sent to the target public by the Post Office [3]. According to Serra et al. [4] only $26.46 \%$ of dental professionals use direct mail as a marketing tool and because of the growth and ease of the Internet, the trend is that this number will decrease even more.

Merchandising can replace advertising in some cases, advertising and selling the service through brands and images. A merchandising option would be the so-called social marketing, which uses support in social causes, lectures and voluntary work as a way of valuing and respecting the image of the professional $[3,14]$.

\section{Digital marketing}

The concept of commercial relationship, after the presence of the Internet, underwent great changes and marketing needed to adapt to this new digital reality, which today is widely explored by the most diverse sectors of the market. Digital marketing, a type of external marketing, is an effective and simple option, from which the professional has the right to dispose, provided in an ethical way $[6,7]$.

It is possible to use digital media in both the capture of new clients and the loyalty of those in service, using Internet resources to disseminate dental knowledge, about the clinic and its services, as well as encouraging communication between potential clients and the CD. However, it is necessary to carry out market research on the wishes, wishes and expectations of the local public about the dental clinic, procedures and professionalpatient relationship, investigating which digital platforms are most used by their potential clients to define the digital assets that (blogs, social networks, websites, mailings, etc.) [3].

There was a great growth in the use of the Internet as a vehicle for communication and marketing of dental clinics after updating the CED in 2012. In a study conducted by Serra et al. [4], it was found that only 61 professionals from a total sample of 975 used it, however, recent research has found an increasing number of pages (websites and social networks) used as a dental marketing tool $[6,7,22]$.

The Internet has been a space of social interaction, creation and sharing of content, which encourages communication and exchange of information among users. This new medium is denoted "social media", which operates as a complement to digital marketing [3].

South America is the second continent that most actively uses social media. The network that dominates the largest number of users in the world is Facebook $\AA$, followed by Whatsapp $\AA$, although other networks are growing in number of users, as is the case of Instagram ${ }^{\circledR}$ and Twitter ${ }^{\circledR}[22]$.

Health professionals can benefit from using social media as an advertising vehicle, since the public in this area traditionally values interpersonal relationships, since this attitude shows attention and generates a sense of security and fidelity between the parties. The service market has undergone several changes over the past decades, intensifying competition among increasingly well-trained professional service providers, and increasing customer demand, making relationships decisive in creating 
business value. It is relationship marketing acting externally to the clinical environment, in the digital environment [13,18-20].

With the growth of social networks, many market sectors, including dentistry, have come to value networks such as Facebook ${ }^{\circledR}$ and Instagram ${ }^{\circledR}$ as useful marketing tools and have been widely used in advertising because they are of great and easy reach to the public, which uses them daily [7].

Through social networks, people can contact institutions to communicate with other patients, as a forum, and thus obtain information about the satisfaction of those who already use the services provided $[23,24]$. Miranda et al. [6], in their research, stated that only $6.51 \%$ of the analyzed websites have room to witness patients' experience, which may demonstrate the lack of information about the possibility of using this tool as a positive visualization of clinic services.

The "content marketing" strategy, which can be used both on social networks, as well as on websites and blogs, is effective in the fact that content is focused on the real need of the reader, rather than the product or service sold. In this way the company interacts subtly with the consumer, who will have a positive view about the clinic [1].

Among the elements of the Marketing Mix, the "Product / Service" and "Value Perceived by the Customer" are necessary for the success of digital marketing. In the "Product / Service" is included the technique and updating of the professional, that is, his investment in courses, new procedures and equipment. Posts on social networks regarding an ongoing postgraduate course or a conference where you are a speaker or a listener demonstrate as a form of personal marketing, that the professional seeks technical and theoretical excellence, as well as expressing his authority over what he says and does [ 5,17].

As for the "Value perceived by the client", the professional must connect with the people, having knowledge about real techniques of attraction, engagement, influence, persuasion and sales, through mental triggers or patterns of automatic behavior. One such trigger would be to tell a story, for this simple action connects and attracts attention. Therefore, instead of starting a publicity text talking directly about a service, it is pertinent to narrate a story to justify its importance, since there is a tendency for the human being to follow the line of thought or the actions of the majority, especially when there is uncertainty [15].

Therefore, it is effective to enumerate the number of treatments performed, number of satisfied patients, and evidence followers, tannings, visualizations, etc., thus reaching the decision of the reader and possible client. This pattern of behavior is further enhanced if the information is specific, as people tend to rely on specific numbers that replace vague expressions. Another mental trigger is the principle of reciprocity, where the human being has the need to reciprocate a kindness. Here is the use of congratulatory messages for customers' birthdays, sent by email or posted on social networks, such as in What's App ${ }^{\circledR}[15,17]$.

Social networks (and other sites) are also useful when sharing links, pop-ups and banners that lead the potential customer directly to the clinic's website. For most patients, the Internet is one of the first sources of information to be consulted for both symptom and treatment research and local practitioners, as well as establishing connections with other patients. Well-designed sites can help practitioners meet many of these potential needs of their patients [24,25].

An interactive, user-friendly website with an intuitive design that serves as a good source of information for the public is a smart and useful platform, enabling patients to review the dental team, report on the services provided at the clinic, and read about the experiences of other patients, thus comparing these factors with other competing practices [24]. The site should be kept up-to-date with new information 
and articles on scientific discoveries in the dental field, as an outdated platform can have a negative impact on the company's image. It should also be emphasized that there is no rule that requires the display of the date of the last update of the website, but that the presence of this website is well viewed by users, since it increases the credibility by demonstrating that the information is not obsolete [6].

The patient should also be encouraged to visit the site, either by clinic staff or by leaflets, banners or other media in the media (social networks, television, billboards, etc.). One advantage of websites is that internet users interested in dental care can view it through any search page, using keywords [24,25].

Each user survey is archived, indicating that one of your interests is listed. Personal information (such as telephone, profession and hobbies) is provided at the time of registration on websites of high traffic companies, such as in social networks or virtual stores. Also stored are information such as location, travel, travel and internet browsing times. In this way, announcements of dental clinics will be launched precisely to the target public that has been researching on "dentists", "orthodontic treatment", "channel", etc. There are consulting and marketing firms specialized in leveraging this result, called remarketing $[25,26]$.

However, there are simple ways to start this process, for example, using a professional page on Facebook ${ }^{\circledR}$, since when publishing something on a personal page, the algorithm of the network itself does not allow a vast view of this content. This contrast with the professional page where the $\mathrm{CD}$ can boost some of its main publications, paying the social network so that these ads are visualized by thousands of people, previously selected by the professional, who will be their target audience. Other companies, such as Instagram ${ }^{\circledR}$ and Google ${ }^{\circledR}$ use this remarketing process [26].

\section{Ethical precepts on marketing, advertising and advertising in dentistry}

Undoubtedly, marketing, be it traditional or digital, is of paramount importance in the competitive reality of the service market present today. Ethical principles, however, must be critically obeyed. Contrarily, researches have pointed to a great failure among professionals to follow the laws of the CEO (Tables 1 and 2) [5-7,9,27,28].

In the dental field the CED is a set of rules that govern the rights and duties of the $\mathrm{SD}$, being easily found, including in the digital environment, where it is made available freely and free to all professionals and lay people. However, a survey that looked at professional websites and dental clinics exposed ethical violations on most of the digital pages included as a sample study [6].

According to Paranhos et al. [9], the Consumer Protection Code also guides marketing in all sectors, including in the service market, maximizing the reporting requirements, truthfulness, availability and transparency of advertisements for dentists and dental clinics to the public.

According to the CED, approved by resolution Federal Council of Dentistry (FCD)-118/2012, ads, advertisements and advertisements can be made in any medium, including the digital medium, provided they comply with the rules. At the moment of disclosure of clinics and / or professionals, it is mandatory to include name and number of natural or legal person, as well as the representative name of the profession "surgeon-dentist". If it is a legal entity, the name and registration number of the technical responsible, in addition, when specialties are mentioned, the name of the professional experts and their qualifications, as well as the areas of practice of the general practitioners should be displayed $[27,28]$. 
Table 1- Percentage of ethical precepts obeyed and infractions committed according to different researches

\begin{tabular}{|lcccc}
\multicolumn{1}{c}{ Ethical precepts } & Serra et al. [4] & Garbin et al. [5] & Miranda et al. [6] & Lima et al. [7] \\
\hline Dentist's name" & Uninformed & $70.8 \%$ & $94.79 \%$ & $98.83 \%$ \\
\hline CR0 $^{1}$ registration number & Uninformed & $65.2 \%$ & $52.34 \%$ & $14.79 \%$ \\
\hline Representative name of "dental surgeon"1 & Uninformed & $34.3 \%$ & $11.46 \%$ & $7.39 \%$ \\
\hline General "clinical expression" when nota specialist" & Uninformed & $40.3 \%$ & $2.34 \%$ & Uninformed \\
\hline Before-after pictures" & $5.95 \%$ & Uninformed & $53.12 \%$ & $46.30 \%$ \\
\hline Prices and payment methods $^{2}$ & $6.6 \%$ & $1.7 \%$ & $5.99 \%$ & $7.77 \%$ \\
\hline Critique of techniques used by other professionals $^{2}$ & Uninformed & Uninformed & Uninformed & $0.38 \%$
\end{tabular}

Foot Note: ${ }^{1}$ - Ethical precepts; ${ }^{2}$ - Ethical breaches.

Table 2 - Comparison between the most ignored ethical precepts and what the CED determines about them

\begin{tabular}{|c|c|}
\hline The ethical precepts most ignored by SDs & Standards set by CED \\
\hline $\begin{array}{l}\text { Obligatory presence of the representative name of "dental surgeon" } \\
\text { AND } \\
\text { Obligation of the presence of the CRO registration number }\end{array}$ & $\begin{array}{l}\text { Art. } 43 . \text { In the communication and disclosure it is mandatory to include } \\
\text { the name and registration number of the individual or legal entity, as well } \\
\text { as the representative name of the profession of dental surgeon and also } \\
\text { of other regulated auxiliary professions. In the case of legal entities, also } \\
\text { the name and the registration number of the responsible technician. }\end{array}$ \\
\hline $\begin{array}{l}\text { Requirement of the expression "general practitioner" when the } \mathrm{CD} \\
\text { performs dental procedures using knowledge obtained at the undergra- } \\
\text { duate }\end{array}$ & $\begin{array}{l}\text { Art. } 43 . \S 1^{\circ} \text {. Communication and disclosure may also include: } \\
\text { VI- The term "general practitioner”, by professionals practicing activities perti- } \\
\text { nent to Dentistry arising from of knowledge acquired in the course of gradua- } \\
\text { tion or post-graduation }\end{array}$ \\
\hline Presence of forbidden expressions or before and after images & $\begin{array}{l}\text { Art. } 44 \text {. It constitutes an ethical infraction: I - to make advertising and } \\
\text { advertising misleading, abusive, including with expressions or images } \\
\text { from before and after, with prices, free services, payment modalities, or } \\
\text { other forms that imply commercialization of Dentistry or contrary to the } \\
\text { provisions of this Code. }\end{array}$ \\
\hline
\end{tabular}

A worrying factor is that only $34.8 \%$ of the office plaques observed by Garbin et al. [5] presented the registration number of the Regional Council of Dentistry (RCD) and that in most of them the representative name of the profession "dental surgeon" was replaced by terms like "dentist" or "dentistry".

These results are similar in the digital media, where almost all professionals do not display the Regional Council of Dentistry (RCD) (85.21\%) personal or legal registration number nor does it disclose the representative name of the profession (92.61\%) in their social networks. This is also observed in the websites, where only $52.34 \%$ show the enrollment number and only $11.46 \%$ the mandatory term "dental surgeon" [6,7].
It is permitted, but not mandatory, to include areas of practice, procedures and treatment techniques recognized by the CFO, provided they precede the specialty degree or the qualification of general practitioner. It may include titles of academic formation 'stricto sensu' and teaching related to the profession and the expression "general practitioner" for professionals who practice dentistry with knowledge acquired in undergraduate or postgraduate courses [27].

In the studies by Serra et al. [4], only $26.46 \%$ of the professionals exhibited their dental specialty and only $7.79 \%$ of them, their academic title in marketing tools. However, in $94.79 \%$ of the websites the information about the specialty registered in the RCD was 
exposed, due to the facility that provides in the moment of research of the public in the platforms of search [6]

It is also possible to have a logo, as well as information on address, telephone, fax, e-mail address, working hours, agreements, credentials and if home and hospital care is offered [26].

It is judged an ethical violation when advertising and advertising is misleading, abusive and disloyal [28]. It is forbidden to include expressions or images of before and after, prices, free services, payment modalities (and commercialization of dentistry in general), to disclose titles and specializations that are not registered or recognized by the FCD, as well as areas, therapies and treatment techniques which are not scientifically proven [27].

It is also considered an ethical infraction to criticize other techniques or professionals as outdated, to give consultation, diagnosis or prescriptions by any mass media, to divulge any element that identifies the patient, if there is no informed consent form (ICF) [26,27].

According to Serra et al. [4] in 2005, only $5.95 \%$ of dentists (SDs) used "before, during, and after" images in their ads. With the advent of the internet, that number has grown substantially. In social networks, the index is $46.30 \%$ [7] and the websites is $53.12 \%$ [6]. This type of announcement causes the patient to believe that the completion of their treatment will be similar to that of the images, grounding the erroneous idea that dentistry has an obligation of result [9]. Others expose prices, free services and payment modalities, whether in digital or traditional marketing tools [5-7].

The study by Lima et al. [7] also showed that in a small number of social networks linked to the SD $(0.38 \%)$, there were criticisms of techniques or materials used by other professionals, which constitutes a passive ethical infraction of penalty, even though in $100 \%$ of them there was no evidence of direct criticism of other professionals.

In most of the websites analyzed, it was stated that the SD would be an expert, but only as a marketing tool, considering that this is a more popular expression than the general practitioner. Although it is considered legal to use it, followed by the area of practice that the professional exercises with his / her knowledge absorbed from the undergraduate course (General practitioner - Endodontics, for example), this act is considered as misleading and therefore prohibited from being performed in any marketing tool [6].

There is a need for education and awareness of the professionals, as well as the greater performance of the agencies responsible for the supervision of dental marketing, pointing out, warning and penalizing the violations found [5].

\section{DISCUSSION}

The authors Paim et al. [1] and Paranhos et al. [10] agreed that marketing is a set of studies, strategies and practices that launch a product or service to the public, according to the analysis of their needs, seeking to maintain its success in the market, thus constituting the success of the company. Marketing can be divided into internal and external and, although separated for didactic purposes, must be an active set of artifices [3]. According to Garbin et al. [5] and Lima et al. [7], external marketing is the most used to attract customers, but several authors corroborate with the idea that this is just a complement to other types of marketing, which should not be ignored $[3,20,23]$.

It was observed that good care is more prominent in satisfaction surveys, even before the professional titration or the determined prices [5,12-14]. According to Guimarães 
Júnior et al [16], there is a current search to revitalize relationship marketing, which has also been commented by other authors when affirming that the clinic should be willing to listen to clients so that the services provided are always exceeding expectations of them and that can be recommended to other people $[17,18]$.

It is necessary that the SD researches the digital platforms most used by its potential customers [3]. According to Rollsz et al. [22], the network that dominates the largest number of users in the world is Facebook ${ }^{\circledR}$, followed by Whatsapp ${ }^{\circledR}$, however, Lima et al. [7] stated that many market sectors, including dentists, are increasingly using Facebook ${ }^{\circledR}$ and Instagram ${ }^{\circledR}$ as useful marketing tools.

Some authors are unanimous in affirming that the strategy of "content marketing" can be used both in social networks, as in websites and blogs, and is effective because it focuses on the real need of the reader. The digital pages should have an intuitive design, serving as a good source of updated information for the public, showing the date of the last update [6, 24-26].

An interesting factor is that both the research done by the user and the information provided by the user is archived and can be used by so-called remarketing. From simple means of using this tool, with publications in social networks, to the hiring of specialized marketing companies in this service [24-26].

Undoubtedly, marketing, be it internal or external, is of paramount importance in the competitive reality of the market of services. Ethical principles, however, must be carefully obeyed. Conversely, studies have pointed to a major flaw between SDs and dental clinics in following the laws of the CED $[5,7,9]$. In the study by Garbin et al. [5] 55.1\% of the dental plaques analyzed were in disagreement with the CED. In the websites observed by Miranda et al. [6], at least $97.66 \%$ of them disobeyed the ethical precepts by not having the expression "general practitioner" by professionals who practice dentistry, with the knowledge acquired in the undergraduate course.

In social networks the results are equally alarming, since $92.61 \%$ of the professionals do not use the mandatory term of identification of the profession "dental surgeon" in its pages, characterizing disagreement with the CEO [7]. This is probably due to the lack of knowledge of the CDs on the standards in force in the CEO, updated in 2012. There is a need for greater awareness of the professionals, as well as the intensive action of the agencies responsible for the supervision of dental marketing, pointing out, warning and penalizing the violations found.

Authors also agreed that in the training of dentistry students need to be encouraged studies of ethics, management and marketing of the profession, as well as technical and theoretical studies. As well as the already active CDs need to be in constant research and updating, since ethical principles must be observed and obeyed at all stages of their professional lives $[2,5,7,18]$.

\section{CONCLUSION}

Digital marketing has shown to be of great importance in the dental services market if, together with other types of external and internal marketing, it obeys the ethical precepts of the Dental Ethics Board. There is great acceptance of digital marketing by dental surgeons, both through websites and through social networks, but there has been a failure to comply with the ethical precepts in force in the Code of Ethical Dentistry.

\section{REFERENCES}

1. Paim AP,Camargo, AC, Silva ACM, Nóbrega FM, Cardoso MC. Marketing in Dentistry. Biosciences Journal. 2004;10(4):223-9. 
2. Miranda S, Bulcão J,Dultra C. Advertising and publicity in dentistry: evaluation of the ethical aspects involved. RBOL - Braz J Legal Dent. 2015;2(1):53-67. doi: 10.21117/rbol.v2i1.21

3. Lucietto DA, Sagaz SM, Zasso FM, Freddo SL. Marketing for health: concepts,possibilities and trends. Tecnological Magazine. 2015 Ago;3(2):30-51.

4. Serra M, Garcia P,DottaE,Gonçalves P.Marketing tools used by dental Surgeons. RG0. 2005;53(2):85-164.

5. Garbin A, Orenha E, Garbin C, Gonçalves P. Advertising in dentistry: evaluation of the ethical aspects involved. RG0.2010;58(1):85-9.

6. Miranda G, Radicchi R, Daruge Júnior E. Analysis of websites of dentists on ethical and legal aspects related to advertising. Rev Bras Odontol. 2013;70(1):80-4.

7. Lima A, Cruz R, Silva R. Analysis of the profiles of dental clinics and dentists in two social networks regarding the ethical, advertising and publicity aspects. RBOL - Braz J Legal Dent. 2016;3(2):66-73. doi: 10.21117/rbol.v3i2.6.

8. Edmunds M, Fulwood C. Strategic communications in oral health: influencing public and professional opinions and actions. Ambul Pediatr. 2002;2(2 Suppl):180-4.

9. Paranhos LR, Benedicto EN, Fernades MM, Viotto FRS, Daruge Júnior E. Ethical and legal implications of marketing in dentistry. RSBO.2011 AbrJun;8(2):219-24.

10. Vasudevan R.E-mail Marketing.J Contemp Res Manage.2010 OctDec;5(3):37-42

11. Esperidião M, Trad L. User satisfaction rating: theoretical-conceptual considerations. Public Health Cad. 2006;22(6):1267-76.

12. Garbin A, Garbin C, Tiano A, Carvalho M, Fagundes A. Marketing in dentistry: the perception of the client regarding the dental service of private clinic. Rev Odontol UNESP.2008:37(2):197-202

13. Arcier N, Silva M, Arcieri R, Gabrin C. The importance of dental marketing to face a competitive market. Araçatuba Dentistry Journal. 2008;29(1):13-9.

14. Viola N, Oliveira A, DottaE. Marketing in Dentistry: a tool that makes the difference. Rev Bras Odontol. 2011;68(2):248-51.

15. Delaney N. The benefits of marketing in orthodontics. Br J Orthod 1998;25(4):322-4. doi: 10.1093/ortho/25.4.322.
16. Guimarães Júnior E, Silva S, Gonçalves J. Marketing in dental services: practices and results from the perception of professionals. Revista da UIIPS 2015;3(2):44-62.

17. Lun J, Sinclair S, Whitchurch E, Glenn C. (Why) do I think what you think? Epistemic social tuning and implicit prejudice.JPers Soc Psychol. 2007;93(6):957-72. doi:10.1037/0022-3514.93.6.957.

18. Sponchiado Júnior EC, Lopes LPB, Marangoni SM. The application of marketing in the dental area. JEduc Theories Pract. 2017 Jul-Set;16(1):10-4.

19. Medeiros F,Lima V. Relationship Marketing:A Competitive Advantage for Dentistry Professionals. RFARN. 2001 Jul-Dez;1(1):33-44.

20. Sassi C, Francesquini Júnior L, Fernandes M, Picapedra A, De Bragança D, Daruge Júnior E. Effective use of dental marketing in the Uruguayan cooperative field. Actas Odontol. 2011 Jul;:8(1):5-13.

21. Filipe S, Simões $D$. The use of the internet and social media by young people: an opportunity for marketing communication? PRISMA.COM. 2015;(27):38-56.

22. Rollsz K, Hansen M, Jackson D, ElliottD. How health care professionals use social media to create virtual communities: an integrative review. JMed InternetRes. 2016 Jun;18(6):1-19. doi: 10.2196/jmir.5312.

23. Zuchini A, Lolli M, Lolli L, Lolli H. Professional profile of surgeon-dentist in association with knowledge and use of marketing. Arq Odontol. 2012 Jan-Mar; 48(1):19-25.

24. Radu G, Gheorghe C, Hostiuc M, Bulescu I,Purcarea V. The adaptation of health care marketing to the digital era. J Med Life. 2017;10(1):44-6.

25. Clarkson E,Bhatia S. Management and Marketing for the General Practice Dental Office. Dent Clin North Am. 2008;52(3):495-505

26. OkadaS, Souza E. Digital marketing strategies in the search era. REMark Rev Bras Mark. 2011 Jan-Abr;10(1):46-72.

27. Brasil. Code of Ethical Dentistry. Approved by Resolution FCD-118/2012.2012 [cited 06 november 2017]. Available from:http://cfo.org.br/wp-content/ uploads/2009/09/codigo etica.pdf.

28. ADA. Principles of ethic \& Code of professional conduct. 2018 [cited 23 february 2018]. Available from: https://www.ada.org/ /media/ADA/ Publications/Files/ADA Code of Ethics 2018.pdf.

\section{Ana de Lourdes Sá de Lira} (Corresponding address)

Universidade Estadual do Piauí, Faculdade de Odontologia

Rua Senador Joaquim Pires 2076 Ininga

CEP: 64049-590 Teresina-PI-Brasil

Fone (86) 999595004

Date submitted: 2017 Dec 08

email: anadelourdessl@hotmail.com 